\title{
INFLUENCE OF NEONATAL TREATMENT WITH 6-HYDROXYDOPA ON CLONIDINE-INDUCED LOCOMOTOR STIMULATION IN THE INFANT RAT
}

\author{
Yasuyuki NOMURA \\ Department of Pharmacology, Institute of Pharmaceutical Sciences. \\ Hiroshima University School of Medicine, Kasumi 1-2-3, Minami-ku, Hiroshima 734, Japan
}

Accepted July 7, 1983

Several studies have shown that clonidine produces locomotor stimulation in the infant rats aged 1 to 14 days, but causes hypoactivity in the adult animals $(1-4)$. The fact that clonidine-induced locomotor stimulation is reduced by a preceding intraperitoneal injection of several $\alpha$-adrenoceptor antagonists, suggests that clonidine induces locomotor stimulation by activating $\alpha$ adrenoceptors in the central nervous system of the infant rat (5). In the adult rats, $\alpha$ adrenoceptors which mediate clonidineinduced sedation more resemble the peripheral presynaptic $\alpha$-adrenoceptors than the postsynaptic ones (6). Furthermore, it has been suggested that clonidine predominantly activates presynaptic $\alpha$-adrenoceptors and thereby induces sedation in the adult rats (7). while Spyraki and Fibiger (8) have suggested that the clonidine-induced sedation is mediated by postsynaptic $\alpha_{2}$-receptors in adult rats. In addition to this controversial idea, it is not clear how reversal in the locomotor effect of clonidine occurs during postnatal life in rats.

To gain insight into the mechanism of the locomotor effect of clonidine in developing rats, the author investigated the effects of neonatal treatment with 6-hydroxydopa (6OHDOPA) on clonidine-induced behavioral changes in 7-day-old rats.

Seven-day-cld Wistar rats of either sex were used. After birth, all litters were culled to 10-12 litters/mother. 6-OHDOPA (75 mg/ $\mathrm{kg}$ ), dissolved in saline solution containing $0.001 \mathrm{~N} \mathrm{HCl}$, or vehicle was first injected subcutaneously (s.c.) into rats within several hr after birth, followed by s.c. injection at 2 and 4 days. Treated pups were kept with a mother under daylight conditions at $23^{\circ} \mathrm{C}$. Locomotor activity of each rat was measured in a plastic cage $(24 \times 18 \mathrm{~cm})$ with an ANIMEX activity meter (Type S. LKB Instrument, sensitivity: $40 \mu \mathrm{A}$ ) by the method previously reported (5). The recording began $10 \mathrm{~min}$ after the s.c. injection of clonidine $\left(2.0 \times 10^{-7} \mathrm{~mol} / \mathrm{kg}\right.$ or $\left.7.8 \times 10^{-7} \mathrm{~mol} / \mathrm{kg}\right)$. Locomotor activity was measured for $10 \mathrm{~min}$ every $20 \mathrm{~min}$ for a period of $90 \mathrm{~min}$ and expressed as counts $/ 50 \mathrm{~min}$. Other behaviors of wall climbing, forward crawling, body tremor and single clonic jerk were carefully observed and recorded during the measurement of locomotor activity. Clonidine hydrochloride was generously provided by C.H. Boehringer Ingelheim Ltd: 6-OHDOPA hydrochloride was kindly donated by NipponRoche Research Center.

A s.c. injection of clonidine $\left(2.0 \times 10^{-7} \mathrm{~mol} /\right.$ $\mathrm{kg}$ or $7.8 \times 10^{-7} \mathrm{~mol} / \mathrm{kg}$ ) induced intense forward crawling, wall climbing, head raising and body tremor initiated by single clonic jerk and resulted in a significant increase in locomotor activity (Fig. 1). Neonatal treatment with 6-OHDOPA attenuated clonidineinduced wall climbing and forward crawling and significantly reduced clonidine-induced locomotor stimulation (Table 1). However. 


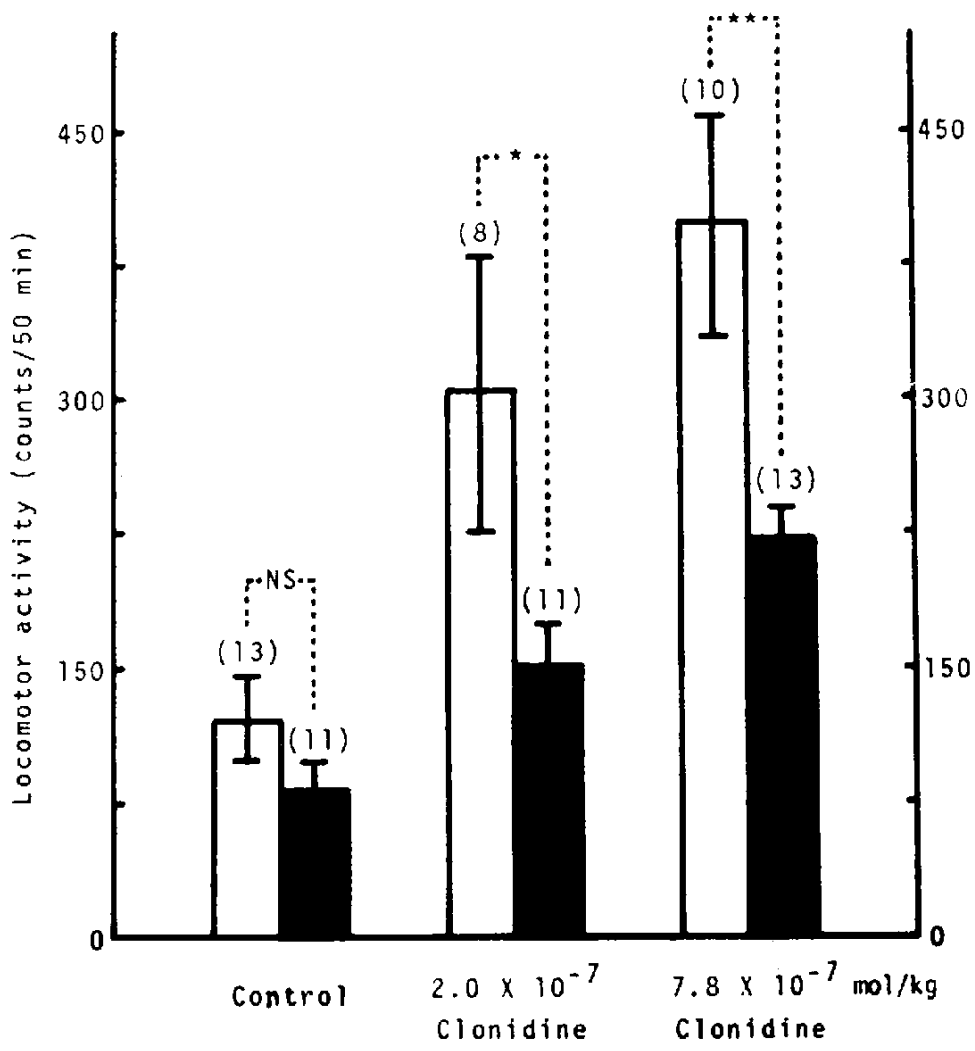

Fig. 1. The effect of neontal treatment with 6-fydroxydopa on clonidine-induced locomotor stimulation and behavioral changes in the infant rats. 6 -Hydroxydopa (75 $\mathrm{mg} / \mathrm{kg}$ ) was injected s.c. into the newborn rats on days 0,2 and 4 . Animals were s.c. injected clonidine $\left(2.0 \times 10^{-7} \mathrm{~mol} / \mathrm{kg}\right.$ or $\left.7.8 \times 10^{-7} \mathrm{~mol} / \mathrm{kg}\right)$. Locomotor activity was measured, and behavior was observed. The results are the mean effects on locomotor activity (counts/50 min): vertica! bars show S. E. of the mean values. Hatched columns are 6-hydroxydopa-treated groups, and open columns are vehicle-treated groups. ${ }^{*} \mathrm{P}<0.05$ and ${ }^{*} \mathrm{P}<0.01$ vs. vehicle treatment. NS: not significant vs, vehiclo treatment.

Table 1. Influonce of clonidine on general benaviors in 7 -day-old rats pretreated with 6-hydroxydopa

\begin{tabular}{|c|c|c|c|c|c|c|}
\hline \multirow{2}{*}{$\begin{array}{l}\text { Treatment } \\
\text { (mol/kg) }\end{array}$} & \multirow{2}{*}{ Protreatment } & \multirow{2}{*}{$\begin{array}{c}\text { The number } \\
\text { of } \\
\text { animals }\end{array}$} & \multicolumn{4}{|c|}{ General behaviors } \\
\hline & & & $\begin{array}{c}\text { Wall } \\
\text { crimbing }\end{array}$ & $\begin{array}{l}\text { Forward } \\
\text { crawling }\end{array}$ & $\begin{array}{l}\text { Body } \\
\text { tremor }\end{array}$ & $\begin{array}{c}\text { Clonic } \\
\text { jerk }\end{array}$ \\
\hline \multirow[t]{2}{*}{ Saline } & Vohido & 13 & - & \pm & - & - \\
\hline & 6-OHDOPA & 11 & - & - & - & - \\
\hline Clonidine & Vetricle & 8 & $+\div$ & ++ & + & 1. \\
\hline $2.0 \times 10^{-7}$ & 6-OHDOPA & 11 & \pm & + & $\because$ & ++ \\
\hline Clonidine & Vehicle & 10 & $++t$ & +++ & + & + \\
\hline $7.8 \times 10^{-7}$ & 6-OHDOPA & 13 & + & ++ & $+t$ & $-t+$ \\
\hline
\end{tabular}

6-Hydroxydopa, $75 \mathrm{mg} / \mathrm{kg}$. was injected s.c. into neonatal rats on days 0.2 and 4 . Animals were s.c. injected witli clonidine $\left(2 \times 10^{-7} \mathrm{o}^{+} 7.8 \times 10^{-7} \mathrm{~mol} / \mathrm{kg}\right)$. Wall climbing, forward crawling, body tremor and clonic lerk were observed for a period of $90 \mathrm{~min}$ after an injection of clonidine. Behavioral responses

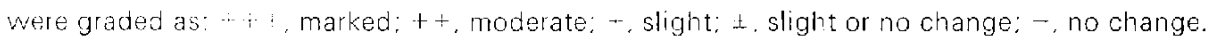


body tremor and single clonic jerk induced by clonidine were more frequent in 6-OHDOPAtreated infant rats than in control ones (Table 1).

In comparison to cionidine-induced hypoactivity in adults (4), the drug caused hyperactivity in 7-day-old rats. The different locomotor effects of clonidine in developing animals may reflect the regional variation of developing stage when noradrenaline (NA) neurons innervate and functionally maturate (9). The results presented here also show that the neonatal treatment with 6-OHDOPA reduced clonidine-induced locomotor hyperactivity such as wall climbing and forward crawling, but slightly increased clonidineinduced body tremor and single jerk. S.c. injection of 6-hydroxydopamine (6-OHDA) (100 $\mathrm{mg} / \mathrm{kg}$, days 1,3 and 5 after birth) caused a significant reduction in telediencephalon NA content in 7-day-old rats (10). We found that $10^{-7} \mathrm{M}$ clonidine significantly decreased $20 \mathrm{mM} \mathrm{K} \mathrm{K}^{+}$-induced $\mathrm{L}-\left[{ }^{3} \mathrm{H}\right] \mathrm{NA}$ release from cerebral cortical slicos in the 7 -day-old rats (11). Therefore, it is presumable that neonatal treatment with 6 OHDOPA degenerates presynaptic terminals of NA neurons in which clonidine acts and subsequently inhibits NA release. Thus the receptors which mediate clonidine-induced locomotor hyperactivity could be presynaptic $\alpha_{2}$-adrenoceptors in the central nervous system of the infant animals. This is consistent with our previous observations that yohimbine and piperoxane (preferential blockers of $\alpha_{2}$ adrenoceptors) have high $\mathrm{oA}_{2}$-values than phenoxybenzamine (a blocker of $\alpha_{1}$ adrenoceptor) against clonidine-induced hyperactivity in infant rats (5). On the other hand, the increasing effect of clonidine on body tremor and single jerk was enhanced by neonatal 6-OHDOPA, indicating that in the infant rats, central $\alpha_{2}$-adrenoceptors mediating these behaviors may largely be located postsynaptically since up-regulation in postsynaptic $\alpha_{2}$-receptors seems to occur on day 7 following 6-OHDOPA treatment on days 0,2 and 4 . The brain stem NA content is elevated following neonatal treatment with 6-OHDOPA $(12,13)$ in the 2 -week-old rats, which is explained by collateral accumulation. in contrast to reduction in telediencephaion NA content by 6-OHDA (10). It is not ruled out that the modification in the behavioral effects of clonidine by 6-OHDOPA treatment may originate from 6-OHDOPAinduced changes of regional innervation of NA neurons during early development. Although 6-OHDOPA attenuated clonidineinduced locomotor hyperactivity such as wall climbing and forward crawling, 6-OHDOPA rather enhanced clonidine-induced body tremor and single jerk. Thus the two kinds of behaviors elicited by clonidine seem to be due to its stimulation of different sites (receptors and/or brain regions) in the infant animals.

Acknowledgements: The author wish to express gratitude to Drs. Y. Yamada, H. Nakai and 1. Kuruma of the Nippon-Roche Research Center for their gift of 6-hydroxydopa hydrochloride and to Boehringer Ingelheim Ltd. for the gift of clonidine hydrochloride.

\section{References}

1) Kellogg, $C$. and Lundborg, P.: Ontogenetic variations in responses to L-DOPA and monoamine receptor-stimulating agents. Psychophamacologia (Berlin) 23, 187-200 (1972)

2) Reinstein, D.K. and Isaacson, R.L.: Clonidine sensitivity in the developing rat. Brain Res. $135,378-382(1977)$

3) Nomura, Y., Oki, K. and Segawa, T.: Pharmacological characterization of central $\alpha$ adrenoceptors which mediate clonidineinduced locomotor hypoactivity in the developing rat. Naunyn Schmiedebergs Arch. Pharmacol. 311, 41-44 (1980)

4) Nomura, $Y$ : The locomotor effect of clonidine and its interaction with a-flupenthixol or halopericiol in the developing rat. Naunyn Schmiedebergs Arch. Pharmacol. 313, 33-37 
(1980)

5) Nomura, Y. and Segawa, T.: The effect of $\alpha$ adrenoceptor antagonists and metiamide on clonidine-induced locomotor stimulation in the infant rat. Br. J. Pharmacol. 66, 531-535 (1979)

6) Drew, G.M., Gower, A.J. and Marriott, A.S.: Pharmacological characterization of $x$ adrenoceptors which mediate clonidine-induced sedation. Br. J. Pharmacol. 61, 468P (1977)

7) Żebrowska- Łupina, I., Przegaliński, Słoniec, M. and Kleinrok, Z.: Clonidine-induced locomotor hyperactivity in rats. The role of central postsynaptic $\alpha$-adrenoceptors. Naunyn Schmiedebergs Arch. Pharmacol. 297, 227-237 (1977)

8) Spyraki, C. and Fibiger, H.: Clonidine-induced sedation in rats: Evidence for mediation by postsynaptic $\alpha_{2}$-adrenoceptors. J. Neural Transm. 54, 153-163 (1982)

9) Kohno, Y.: Regional characteristics of nor- adrenaline turnover as reflected in the brain levels of MHPG-SO $\mathrm{SO}_{4}$. Folia Pharmacol. Japon. 81, 175-192 (1983) (Abs. in English)

10) Singh, B. and De Champlain, J.: Altered ontogenesis of central noradrenergic neurons following neonatal treatment with 6-hydroxydopamine. Brain Res. 48, 432-437 (1972)

11) Nomura, $Y .$, Yotsumoto, I. and Nishimoto, $Y$.: Ontogeny of influence of clonidine on high potassium-induced release of noradrenaline and specific $\left[{ }^{3} \mathrm{H}\right]$ clonidine binding in the rat brain cortex. Dev. Neurosci. 5, 198-204 (1982)

12) Zieher, L.M. and Jaim-Etcheverry, G.: Regional differences in the long-term effect of neonatal 6 -hydroxydopa treatment on rat brain noradrenaline. Brain Res. 60, 199-207 (1973)

13) Kostrzewa, R.M. and Harper, J.W.: Effect of 6-hydroxydopa on catecholamine-containing neurons in brains of newborn rats. Brain Res. 69, 174-181 (1974) 